Witcraft 
This page intentionally left blank 


\title{
JONATHAN RÉE
}

\author{
Witcraft \\ The Invention of Philosophy in English
}

Yale UNIVERSITY PRESS

New Haven and London 
First published in 2019 in the United States by Yale University Press and in Great Britain by Penguin Books Ltd., London.

Copyright (C) Jonathan Rée, 2019.

All rights reserved.

This book may not be reproduced, in whole or in part, including illustrations, in any form (beyond that copying permitted by Sections I07 and I08 of the U.S.

Copyright Law and except by reviewers for the public press), without written permission from the publishers.

Yale University Press books may be purchased in quantity for educational, business, or promotional use. For information, please e-mail sales.press@yale.edu (U.S. office) or sales@yaleup.co.uk (U.K. office).

Typeset in I0.2/I3.5 Sabon LT Std.

Typeset by Jouve (UK), Milton Keynes.

Printed in the United States of America.

Library of Congress Control Number: 2019940784

ISBN 978-0-300-24736-7 (hardcover : alk. paper)

This paper meets the requirements of ANSI/NISO Z39.48-1992

(Permanence of Paper).

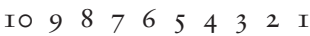

